\title{
Efektivitas penyuluhan dengan media audiovisual terhadap tingkat pengetahuan wanita usia subur mengenai kanker serviks di Puskesmas Tanjung Sekayam Kabupaten Sanggau
}

\author{
Mikhael Zein Fitto ${ }^{1, *}$, Eka Ardiani Putri ${ }^{2}$, Ita Armyanti ${ }^{3}$ \\ ${ }^{I}$ Program Studi Kedokteran, Fakultas Kedokteran, Universitas Tanjungpura, Kalimantan Barat, Indonesia \\ ${ }^{2}$ Departemen Ilmu Kesehatan Masyarakat, Fakultas Kedokteran, Universitas Tanjungpura, Kalimantan Barat, Indonesia \\ ${ }^{3}$ Departemen Bioetika, Fakultas Kedokteran, Universitas Tanjungpura, Kalimantan Barat, Indonesia \\ *Korespondensi: mikhaelzeinfitto@student.untan.ac.id
}

\begin{abstract}
Abstrak
Latar belakang: Kanker serviks menempati urutan keempat keganasan yang menyerang wanita di dunia. Patogenesis kanker serviks dikaitkan dengan adanya infeksi virus HPV tipe 16 dan 18. Pencegahan kanker serviks yaitu dengan menghindari faktor risiko dan melakukan pemeriksaan deteksi dini seperti IVA dan pap smear. Rendahnya pengetahuan menyebabkan kurangnya kepedulian terhadap faktor risiko kanker serviks dan partisipasi wanita usia subur dalam melakukan upaya deteksi dini. Penyuluhan bertujuan untuk meningkatkan pengetahuan wanita usia subur sehingga diharapkan dapat mencegah faktor risiko kanker serviks dan aktif dalam melakukan upaya deteksi dini. Metode: Penelitan menggunakan metode pra eksperimental dengan rancangan one group pretest-posttest. Populasi penelitian seluruh wanita usia subur di Puskesmas Tanjung Sekayam. Sampel penelitian diambil secara accidental sampling dengan jumlah 50 wanita usia subur. Analisis bivariat menggunakan uji T berpasangan. Hasil: Terjadi peningkatan jumlah responden dengan pengetahuan baik setelah penyukuhan, yaitu dari 8 orang menjadi 21 orang. Setelah penyuluhan, mayoritas responden memiliki pengetahuan cukup yaitu sebanyak 25 orang. Hasil uji $\mathrm{T}$ berpasangan menunjukkan nilai $\mathrm{p}=0,000$. Terdapat pengaruh penyuluhan terhadap tingkat pengetahuan sebelum dan sesudah penyuluhan tentang kanker serviks. Kesimpulan: Penyuluhan menggunakan media audiovisual efektif dalam meningkatkan pengetahuan wanita usia subur mengenai kanker serviks.
\end{abstract}

\section{Effectiveness of counseling with audiovisual media toward level of knowledge about cervical cancer among women of childbearing age at Tanjung Sekayam Public Health Center in Sanggau District}

\begin{abstract}
Background: Cervical cancer ranks as the fourth most common malignancy that attacks women in the world. The pathogenesis of cervical cancer is associated with the presence of HPV virus infection types 16 and 18 . Prevention of cervical cancer is by avoiding risk factors and conducting early detection tests such as IVA and pap smears. The lack of knowledge causes a lack of concern for cervical cancer risk factors and participation in women of childbearing age in making early detection efforts. The counseling aimed to increase the women's knowledge so they can avoid cancer risk factors and be actively involved in early detection efforts. Methods: The research used a pre-experimental method with a one-group pretest-posttest design. The study population was all women of childbearing age at the Tanjung Sekayam Public Health Center. Fifty women were included by accidental sampling. Bivariate analysis using paired sample T-test. Results: There was an increase in the number of respondents with good knowledge from 8 to 21 people after the counseling. After counseling, the majority of respondents had sufficient knowledge, as many as 25 people. Paired T-test results showed the p-value of 0.000 . There is an effect of counseling on the level of knowledge before and after counseling about cervical cancer. Conclusions: Counseling using audiovisual media effectively increases the level of knowledge about cervical
\end{abstract}


cancer among women of childbearing age.

Keywords: cervical cancer, woman of childbearing age, counseling, level of knowledge

\section{Pendahuluan}

Kanker serviks menempati peringkat keempat keganasan yang menyerang wanita di dunia. Kasus kanker serviks pada tahun 2018 diperkiraan sebanyak 570.000 kasus baru mewakili 6,6\% dari semua kanker pada wanita dan $7,5 \%$ dari semua kematian akibat kanker pada wanita. Perkiraan kematian akibat kanker serviks lebih dari 311.000 kematian setiap tahunnya. Sekitar $90 \%$ kematian terjadi di negara berpenghasilan rendah dan menengah. ${ }^{1}$ Prevalensi kasus baru kanker serviks di Indonesia diperkirakan sebanyak 32.469 kasus pada tahun 2018 atau 24,5\% dari jumlah kanker yang menyerang wanita. Jumlah kematian akibat kanker serviks terbanyak kedua akibat kanker dan diperkirakan sekitar 18.279 pada tahun 2018 di Indonesia. ${ }^{2}$

Data Seksi Pencegahan dan Pengendalian PTM dan Kesehatan Jiwa Dinkes Prov. Kalbar pada tahun 2018 menunjukkan bahwa terdapat 665.354 wanita berusia 30-50 tahun di Kalimantan Barat namun hanya 40.499 atau $6,09 \%$ wanita yang melakukan upaya pencegahan kanker serviks dengan deteksi dini menggunakan metode IVA dan sebanyak 1.505 wanita menunjukkan hasil IVA positif. Di Kabupaten Sanggau, hanya 1.582 dari 5.808 wanita yang melakukan deteksi dini dan ditemukan sebanyak 33 wanita memiliki hasil pemeriksaan positif. ${ }^{3,4}$

Kanker serviks merupakan keganasan akibat infeksi virus HPV 16 dan 18 yang terjadi pada organ serviks atau leher rahim wanita. Tingginya insidensi kanker serviks berhubungan dengan pemanfaatan terbatas atau akses skrining deteksi dini berupa Pap smear atau IVA. Insidensi kanker serviks mengalami penurunan di negara maju tetapi terus meningkat di negara berkembang. ${ }^{5}$

Faktor-faktor risiko untuk infeksi HPV khususnya displasia meliputi melakukan kegiatan seksual dengan banyak pasangan, usia dini berhubungan seksual pertama, dan riwayat penyakit kelamin. Infeksi Human Immunodeficiency Virus (HIV), terutama ketika dikaitkan dengan jumlah sel T CD4 + rendah, dikaitkan dengan tingkat displasia tingkat tinggi yang lebih tinggi dan kemungkinan periode latensi yang lebih pendek antara infeksi dan penyakit invasif. Pemberian terapi antiretroviral sangat aktif mengurangi risiko displasia tingkat tinggi terkait dengan infeksi HPV. Faktor-faktor lain seperti merokok, nutrisi, dan infeksi seksual yang ada bersamaan seperti C. trachomatis, virus Herpes Simplex Tipe 2, dan HIV dapat berkontribusi dalam menentukan perkembangan infeksi HPV pada seorang wanita menjadi kanker serviks. ${ }^{6}$

Risiko menderita kanker serviks 4 kali lebih tinggi pada wanita dengan pendidikan rendah dibandingkan dengan wanita berpendidikan tinggi. Pengetahuan dikaitkan dengan tingkat penghasilan, perilaku seks, dan kebersihan. Wanita yang melakukan hubungan seksual pertama kali pada usia kurang dari 20 tahun lebih berisiko 3 kali menderita kanker serviks dibandingkan dengan wanita yang melakukan hubungan seksual pertama kali diatas 20 tahun. Wanita usia remaja sudah harus dididik tentang pentingnya kebersihan dan vaksinasi genital dalam kehidupan sekolah sehingga hal itu akan membantu untuk menumbuhkan kesadaran mereka saat menginjak kehidupan yang lebih dewasa dan pasti akan mengurangi kejadian infeksi persisten dengan jenis HPV.

Satu di antara kemajuan terpenting dalam diagnosis dan perawatan kanker serviks adalah dimungkinkan pengamatan bahwa kanker ini timbul dari lesi prakanker yang dimulai dengan perkembangan sel serviks atipikal. Sel atipikal berbeda dari epitel skuamosa serviks yang normal. Ada perubahan pada bagian inti dan sitoplasma sel dan lebih banyak variasi dalam ukuran dan bentuk sel. Perubahan prakanker ini merupakan rangkaian perubahan morfologis dengan batas tidak jelas yang secara bertahap dapat berkembang menjadi kanker in situ dan kemudian menjadi kanker invasif, atau dapat secara spontan mengalami kemunduran. ${ }^{8}$

Pemerintah Indonesia mencanangkan program deteksi dini terhadap kanker serviks. Pemerintah menargetkan minimal 50\% wanita berusia 30-50 tahun yang melakukan deteksi dini terhadap kanker serviks menggunakan IVA dicapai pada tahun 2019. Namun dari target yang ditentukan pemerintah, pemeriksaan deteksi dini kanker serviks baru dilakukan oleh sebanyak 2.747 .662 wanita $(7,34 \%)$ hingga tahun 2018. Dari hasil tersebut didapatkan hasil IVA positif sebanyak 77.969 wanita. Upaya 
pencegahan kanker serviks dilakukan dengan deteksi dini menggunakan metode IVA. Kasus IVA positif dapat segera dilakukan tindakan pengobatan dengan krioterapi (lesi pra kanker leher rahim positif). Upaya pencegahan kanker serviks dengan skrining IVA setiap 5 tahun sekali dapat menurunkan kasus $83,6 \%$. 3,9

Pengetahuan merupakan hasil dari tahu dan terjadi setelah seseorang melakukan pengindraan terhadap suatu objek tertentu. Pengindraan terjadi melalui panca indra manusia, yakni indra pendengaran, penciuman, penglihatan, peraba, dan pengecap. Pengetahuan manusia sebagian besar diperoleh melalui mata dan telinga. Secara garis besar terdapat 6 tingkatan pengetahuan yaitu tahu (know), Memahami (comprehension), Aplikasi (application), Analisis (analysis), Sintesis (synthesis), Evaluasi (evalution). ${ }^{10}$

Penyuluhan kesehatan merupakan kegiatan pendidikan kesehatan yang dilakukan dengan menyebarkan pesan, menanamkan keyakinan sehingga masyarakat tidak saja sadar, tahu, dan mengerti tetapi juga mau dan dapat melakukan anjuran yang berhubungan dengan kesehatan. Penyuluhan kesehatan merupakan bagian dari promosi kesehatan yaitu suatu proses pemberdayaan atau memandirikan masyarakat agar dapat memelihara dan menjaga kesehatannya. ${ }^{11}$

Belum tercapainya target deteksi dini kanker serviks disebabkan oleh pengetahuan tentang kanker serviks pada wanita yang masih kurang dan rendahnya kesadaran untuk melakukan upaya deteksi dini. Pengetahuan yang baik tentang kanker serviks diharapkan dapat mengubah pola pikir wanita tersebut agar terdorong melakukan pencegahan sedini mungkin. Letak geografis dan cakupan deteksi dini di Puskesmas Tanjung Sekayam menjadi pertimbangan peneliti dalam menentukan tempat penelitian. Berdasarkan uraian diatas, maka peneliti berminat untuk melakukan penelitian yang bertujuan untuk mengetahui efektivitas penyuluhan dengan metode audiovisual tentang kanker serviks terhadap tingkat pengetahuan di Puskesmas Tanjung Sekayam, Kecamatan Kapuas, Kabupaten Sanggau.

\section{Metode}

Desain yang digunakan dalam penelitian ini adalah pra eksperimen. Rancangan yang digunakan adalah one-group pretest-posttest. Tingkat pengetahuan mengenai kanker serviks diukur sebelum dan sesudah penyuluhan. ${ }^{12}$ Populasi terjangkau pada penelitian ini adalah wanita usia subur di wilayah kerja Puskesmas Tanjung Sekayam, Kecamatan Kapuas, Kabupaten Sanggau. Sampel akan dipilih menggunakan teknik non-probability sampling secara accidental sampling sebanyak 50 wanita usia subur (WUS).

\section{Hasil}

\section{Gambaran umum lokasi penelitian dan responden penelitian}

Puskesmas Tanjung Sekayam salah satu puskesmas di Kecamatan Kapuas, Kabupaten Sanggau. Puskesmas ini beralamat di Jalan Ahmad Yani, Kecamatan Kapuas, Kabupaten Sanggau. Puskesmas ini didirikan dengan dasar hukum Peraturan Bupati (PERBUP) Kabupaten Sanggau No. 34 Tahun 2017. Luas wilayah puskesmas ini adalah 292,74 km2 dengan jumlah penduduk 19.855 jiwa. Penelitian dilaksanakan pada tanggal 21-23 Januari 2020 di tiga desa wilayah kerja Puskesmas Tanjung Sekayam yaitu Desa Sei. Ranas, Desa Sei. Kosak, dan Desa Penyeladi. Penelitian dibantu oleh petugas kesehatan Puskesmas Tanjung Sekayam yang melakukan pemeriksaan IVA kepada masyarakat penduduk desa.

Distribusi frekuensi karakteristik umum subjek penelitian disajikan pada Tabel 1. Jumlah sampel penelitian sebanyak 50 wanita usia subur berusia 30-50 tahun. Kelompok umur terbanyak didapat dari rentang usia 30-35 tahun. Sebagian besar responden sudah pernah melakukan pemeriksaan IVA. Pendidikan terakhir sebagian besar responden berasal dari pendidikan SD.

Tingkat pengetahuan sebelum dilakukan penyuluhan adalah 60,58. Tingkat pengetahuan setelah diberikan penyuluhan mengalami peningkatan menjadi 71,68.

Tabel 2 menunjukkan perbandingan kategori hasil pretest dan posttest dari WUS berusia 30-50 tahun. Pengetahuan terbanyak sebelum diberikan penyuluhan berada pada kategori cukup. Setelah diberikan penyuluhan sebagian besar responden berada dalam kategori pengetahuan cukup. Kategori pengetahuan baik mengalami peningkatan dari 8 menjadi 21 WUS. 
Tabel 1. Karakteristik umum subjek penelitian

\begin{tabular}{lcc}
\hline Karakteristik & $\begin{array}{c}\text { Jumlah } \\
\text { (orang) }\end{array}$ & $\begin{array}{c}\text { Presentase } \\
(\%)\end{array}$ \\
\hline Umur (tahun) & 26 & 54 \\
$30-35$ & 20 & 38 \\
$36-45$ & 4 & 8 \\
$46-50$ & 50 & 100 \\
Total & & \\
Pemeriksaan Deteksi Dini & 26 & 52 \\
IVA & 0 & 0 \\
Pap smear & 24 & 48 \\
Tidak pernah & 50 & 100 \\
Total & & \\
Pendidikan Terakhir & 30 & 60 \\
SD & 12 & 24 \\
SMP & 7 & 7 \\
SMA & 1 & 2 \\
Tidak sekolah & 50 & 100 \\
Total & &
\end{tabular}

Tabel 2. Tingkat pengetahuan tentang kanker serviks sebelum dan sesudah penyuluhan

\begin{tabular}{lcccc}
\hline \multirow{2}{*}{ Penyuluhan } & \multicolumn{2}{c}{ Pengetahuan } & & \multirow{2}{*}{ Total } \\
& Baik & Cukup & Kurang & \\
\hline Sebelum & 8 & 29 & 13 & 50 \\
& $(16 \%)$ & $(58 \%)$ & $(26 \%)$ & $(100 \%)$ \\
Sesudah & 21 & 25 & 4 & 50 \\
& $(42 \%)$ & $(50 \%)$ & $(8 \%)$ & $(100 \%)$ \\
\hline
\end{tabular}

Sumber: Data primer, 2020

\section{Analisis bivariat}

Hasil penelitian yang diperoleh disusun dalam kelompok pretest dan posttest untuk menganalisis signifikansi perubahan frekuensi sebelum dan sesudah penyuluhan terhadap pengetahuan mengenai kanker serviks. Kemudian dilakukan uji $\mathrm{T}$ berpasangan menggunakan program SPSS 23.0. Uji normalitas dilakukan terlebih dahulu menggunakan uji Kolmogorov-Smirnov.

Berdasarkan hasil Uji Kolmogorov-Smirnov didapatkan bahwa data tingkat pengetahuan pretest maupun posttest dalam keadaan normal, sehingga untuk mengetahui efektivitas penyuluhan terhadap tingkat pengetahuan dapat dilakukan dengan uji $\mathrm{T}$ berpasangan. Uji $\mathrm{T}$ berpasangan digunakan untuk menunjukkan pengaruh antara sebelum dan sesudah diberikan penyuluhan.

Hasil uji menunjukkan nilai $\mathrm{p}=0,000$. Nilai $\mathrm{p}<0,05$ menunjukkan bahwa secara statistik terdapat efektivitas yang signifikan pada penyuluhan menggunakan media audiovisual dalam meningkatkan pengetahuan tentang kanker serviks.

\section{Pembahasan}

Penelitian ini dilakukan untuk melihat efektivitas penyuluhan terhadap peningkatan pengetahuan wanita usia subur mengenai kanker serviks. Penyuluhan dilakukan untuk menyampaikan informasi kepada kelompok tertentu dengan tujuan meningkatkan kualitas hidup sehat dan melakukan tindakan pencegahan penyakit. Pengetahuan yang baik mengenai kanker serviks dapat menumbuhkan kesadaran wanita usia subur untuk melakukan tindakan pencegahan seperti menghindari merokok dan berhubungan seksual secara dini yang menjadi faktor risiko terjadinya kanker serviks. Penelitian oleh Deasy ${ }^{13}$ mengungkapkan bahwa terdapat hubungan antara tingkat pengetahuan WUS terhadap partisipasi deteksi dini menggunakan metode IVA.

Pengetahuan wanita usia subur sebagian besar dalam kategori cukup sebanyak 30 orang $(60 \%)$ sedangkan kategori baik sebanyak 7 orang (14\%) sebelum diberikan penyuluhan. Hasil ini juga didukung oleh Syswianti ${ }^{14}$ bahwa sebagian besar responden penelitian memiliki pengetahuan cukup sebelum diberikan penyuluhan tentang kanker serviks menggunakan video. Setelah diberikan penyuluhan, pengetahuan cukup tentang kanker serviks menjadi 25 orang $(50 \%)$ dan pengetahuan baik meningkat menjadi 21 orang $(42 \%)$. Hal ini memperkuat hasil penelitian oleh Saraswati bahwa ada pengaruh pemberian media film terhadap peningkatan pengetahuan kategori baik wanita tentang kanker serviks. ${ }^{15}$ Penelitian oleh Muthia ${ }^{16}$ mendapatkan bahwa penyuluhan menggunakan media audiovisual efektif dalam meningkatkan pengetahuan.

Perhitungan rata-rata nilai pengetahuan wanita usia subur tentang kanker serviks sebelum dilakukan penyuluhan adalah 60,58. Setelah diberikan penyuluhan perhitungan rata-rata nilai pengetahuan mengalami kenaikan menjadi 71,68 . Hal ini sejalan dengan penelitian Tani $^{17}$ bahwa penyuluhan kesehatan dapat meningkatkan nilai rata-rata pengetahuan WUS mengenai kanker serviks. Penelitian oleh Abiodun $^{18}$ menunjukkan bahwa setelah diberikan penyuluhan dengan media film terjadi peningkatan nilai rata-rata pengetahuan pada wanita dewasa tentang kanker serviks. Penelitian yang sejalan juga didapatkan oleh Love ${ }^{19}$ bahwa penyuluhan tentang kanker serviks dengan video edukasi entertainment meningkatkan pengetahuan wanita tentang skrining kanker serviks di California pada wanita Thailand. Peningkatan nilai rata-rata pengetahuan setelah diberikan penyuluhan 
menggunakan media audiovisual tentang skrining IVA juga didukung oleh penelitian Silalahi ${ }^{20}$ dalam meningkatkan perilaku skrining IVA di wilayah kerja Puskesmas Pacarkeling Surabaya.

Berdasarkan hasil perhitungan nilai pretest dan posttest setiap pertanyaan yang dijawab oleh responden menggunakan uji $\mathrm{T}$ berpasangan didapatkan nilai $\mathrm{p}=0,000$. Hasil ini menunjukkan bahwa hipotesis dapat diterima berdasarkan hasil perhitungan analisis data yang dilakukan. Dengan demikian dapat disimpulkan bahwa penyuluhan menggunakan media audiovisual efektif dalam meningkatkan pengetahuan WUS tentang kanker serviks.

\section{Kesimpulan}

Berdasarkan hasil dan pembahasan penelitian yang dilakukan maka dapat disimpulkan bahwa tingkat pengetahuan WUS sebelum penyuluhan tentang kanker serviks menggunakan media audiovisual sebagian besar adalah cukup yaitu 29 orang dengan nilai rata-rata 60,58 dan sesudah penyuluhan tentang kanker serviks menggunakan media audiovisual sebagian besar adalah cukup yaitu 25 orang dengan nilai rata-rata 71,68 . Penyuluhan menggunakan media audiovisual efektif dalam meningkatkan pengetahuan WUS mengenai kanker serviks.

\section{Daftar Pustaka}

1. WHO. 2019. Cervical cancer. [Internet]. Tersedia di https://www.who.int/cancer/prevention/diagnosis-scre ening/cervical-cancer/en.

2. Bruni L, Albero G, Serrano B, et al. Human papillomavirus and related diseases in Indonesia. ICO/IARC Information Centre on HPV and Cancer (HPV Information Centre); 2019.

3. Kemenkes RI. Profil kesehatan Indonesia 2018. Jakarta : Kementerian Kesehatan RI; 2019.

4. Dinkes Kabupaten Sanggau. Profil kesehatan Kabupaten Sanggau 2018. Sanggau: Dinas Kesehatan Kabupaten Sanggau; 2019.

5. Papadakis MA, Stephen JM. Current medical diagnosis
\& treatment. 58th ed. New York : McGraw-Hill; 2019. p.783-786.

6. Fauci A, Eugene B, Dennis K, et al. Harrison's principles of internal medicine. 19th Edition. US : Mcgraw-hill; 2015. p.595-6.

7. Jeevitaa K, Meghnad G J. Genital hygiene and strategies for HPV prevention. Nov Appro in Can Study. 2018;1(2):43-5.

8. Damayanti. Faktor-faktor yang berhubungan dengan kejadian kanker serviks di RSUD Arifin Achmad Pekanbaru tahun 2008-2010. Jurnal Kesehatan Komunitas. 2013;2(2):88-93.

9. Direktorat Jenderal P2PTM. Laporan kinerja tahun 2018. Jakarta: Kementerian Kesehatan RI; 2019.

10. Notoatmodjo, S. Promosi Kesehatan dan Ilmu Perilaku. Jakarta : Rineka Cipta; 2014. h.138-9.

11. Maulana, Heri DJ. Promosi kesehatan. Jakarta : EGC Penerbit Buku Kedokteran; 2009. h.134-7.

12. Notoatmodjo, S. Metodologi penelitian kesehatan. Jakarta: Rineka Cipta; 2012. h.56-7.

13. Deasy M. Hubungan antara tingkat pengetahuan tentang kanker serviks dan keikutsertaan melakukan pemeriksaan inspeksi visual asetat di Puskesmas Alianyang Pontianak. [Skripsi]. Pontianak : Universitas Tanjungpura; 2014.

14. Syswianti D. Pengaruh penyuluhan kanker serviks dengan media video terhadap pengetahuan dan sikap melakukan IVA test. Health Science Growth (HSG) Journal. 2019;4(1):50-64.

15. Saraswati LK. Pengaruh promosi kesehatan terhadap pengetahuan tentang kanker serviks dan partisipasi wanita dalam deteksi dini kanker serviks. [Tesis]. Surakarta : Universitas Negeri Surakarta; 2011.

16. Muthia F. Perbedaan efektifitas penyuluhan kesehatan menggunakan metode ceramah dan media audiovisual (film) terhadap pengetahuan santri Madrasah Aliyah Pesantren Khulafaur Rasyidin tentang TB paru tahun 2015. [Skripsi]. Pontianak: Universitas Tanjungpura; 2015.

17. Tani P, Herlina W, Gresty M. Pengaruh penyuluhan kesehatan tentang kanker serviks terhadap pengetahuan wanita usia subur di desa Sendangan Satu Kecamatan Sonder. ejournal keperawatan (e-Kp). 2018;6(2):1-6.

18. Abiodun OA, Olu-Abiodun OO, Sotunsa JO, Oluwole FA. Impact of health education intervention on knowledge and perception of cervical cancer and cervical screening uptake among adult women in rural communities in Nigeria. BMC Public Health. 2014;14:814.

19. Love GD, Sora PT. Using entertainment-education to promote cervical cancer screening in Thai women. $\mathbf{J}$ Canc Educ. 2012;27:585-90.

20. Silalahi V. Efektivitas audiovisual dan booklet sebagai media edukasi untuk meningkatkan perilaku skrining IVA. Jurnal MKMI. 2018;14(3):304-15. 